DOI: $10.2478 / \mathrm{v} 10318-012-0012-8$

\title{
HONOURING THE WOUND: WAR AND PERFORMANCE IN THE LIVES OF HANNAH SNELL, DEBORAH SAMPSON AND PAULINE CUSHMAN
}

\author{
GEORGINA K. LOCK \\ Nottingham Trent University
}

\begin{abstract}
:
This essay investigates three women's cross-dressed service in the military. Hannah Snell (1723-92) served as a British marine and fought the French in India. Deborah Sampson Gannet (1760-1827) fought the British in the American Wars of Independence and Pauline Cushman (1833-1893) claimed to have disguised herself for the Union during the American Civil War. These three are, by no means, the only women to claim action and remuneration as male combatants (Jelinek 53-62), ${ }^{1}$ when the legal extent of
\end{abstract}

\footnotetext{
${ }^{1}$ See also, The Friendless Orphan, An Affecting Narrative of the trials and Afflictions Of Sophia Johnson.... Johnson served in Anglo-American war of 1812-13 and her arm was amputated after she was wounded. See also: The life, travels and extraordinary adventures of Elizabeth M'Dougald.... The publisher emphasises that the avenging assassin is " a female of good character... and... cannot but hope that she will reap something from the sale of the book, to realise something to enable her to educate her family of small children." (1) This need not reduce veracity since all these narratives seem financially driven. However the following two publications are probably fantasy: The Female Officer, or the wonderful startling and thrilling Adventures of Madeline Moore Who to be Near her Lover Procured a Male Disguise, and joined the late Expeditionary force to Cuba ... An Accurate Description of the Battle, and her own Perilous Adventures and Hair Breadth escapes ... Are Described with a Graphic Power That Will Fairly Make Onee's Blood Tingle With Excitement. The reader may rely upon this narrative, as being strictly authentic; The Woman in Battle: A Narrative of The Exploits, Adventures, and Travels of Madame Loreta, Janeta Vasquez, otherwise known as Lieutenant Harry T Buford, Confederate States Army, in which is Given Full Descriptions of the Numerous Battles in which she Participated as a Confederate officer; Of Her Perilous Performances as a Spy, as a Bearer of despatches, as a secret service agent, and as a Blockade Runner; of her adventures behind the Scenes at Washington...; of her Career as a Bounty and Substitute Broker in New York; of her
} 
women's engagement was as unpaid camp followers. However, all three gave accounts of their military exploits to the public through biographies and solo performances on stage.

Keywords: women, soldier, heroine, nation, commemoration, performance

The stage performances of female soldiers Hannah Snell, Deborah Sampson Gannet and Pauline Cushman commemorate and justify cross-dressing and joining the military by exposing the actual female bodies, which undertook these transgressions. Snell and Sampson marked their conflict with wounds, therefore scars, which prompted curiosity and story. Cushman is remarkable for escaping damage. Nevertheless, the 'scarring' of their gender can be seen as ritual scarification, marks of commitment to their society and/or nation, which framed by appropriate narratives, gain them, and their sex, honour and cultural value.

Dianne Dugaw proposes "the first Female Warriors of English balladry began to appear in print just at the turn of the seventeenth century. By the century's end their stories became a regularized and common place motif." (Dugaw 31) Most broadsides, printed on single sheets of cheap paper, were anonymous, commissioned by publishers from professional hacks and sold by singing pedlars. These pedlars were often women, and regarded as disruptions to the peace because of their poverty and the material they sang. (Fulford 309-29) Ballads about fighting women were feared to encourage female identification with "roaring girls", viragoes who smoked, brawled and wore breeches, and were stock characters of Jacobean drama (Dekker and Middleton). Referenced in Elizabethan and Jacobean performances like Thomas Heywood's Fair Maid of The West, Part One (1609) and Francis Beaumont and John Fletcher's The Scornful Lady (1616), the ballad Mary Ambree whose valorous acts performed at Gant were ... in revenge of her Lovers death, made the virago heroic and gave her a heart.

Mary Ambree's lover is despatched from the beginning. Later ballads replaced the trope of the heroine's passionate vengeance, the catalyst for female action, with her courageous commitment, heart and body, to a living lover. The ballad of The Maiden Sailor, from the 1690s, attributed to "John Curtin, Seaman, on board the Edgar", claims inspiration from a real case, its subtitle relating that it was a true Relation of a young Damsel, who was Pressed on Board the Edgar, Man of War, being taken up in a Seaman's Habit; after being known she was discharged, and at her examination, she declared she would serve the King at Sea, as long as her Sweetheart continued in Flanders. (Pepys 174) The song continues:

Travels in Europe and South America, her mining Adventures on the Pacific Slope; her residence among the Mormons; her Love Affairs, Courtships, Marriages etc. etc. 
Good people e'ery one sir come listen to my ditty

The like was never known Sir a jest both true and pretty Which hear I come for to declare of a very pretty Damsel fair Who changed her cloaths, indeed, And put on Seaman's weed And then she did appear A youth both fair and clear Like to a Seaman rare So that you would swear That she'd been a sailor too.(Pepys 174)

The unsteady flow of lines 5-13 gives the impression that the narrative is a sailor's yarn, which may be just one part of a complete invention. However, given the challenge of survival as a single woman and the lure of earning as much as a man as well as travelling more safely in a man's clothes, it is likely that The Maiden Sailor was built on facts. (cf. Wheelwright 491-2) The narrative frames circumstances which were repeated, not only by later ballads like Blue Eyed Jenny (1790) and Polly Oliver (1823), but by real women serving as sailors or soldiers, who were only discovered by accidents or death.

The Female Warrior ballads give spin to the risk and drudgery of serving in the army or navy. The protagonist's inner conflict is emphasised, as she hides her forbidden gender and frustrated, sacrificial love for a soldier or sailor who is called or press-ganged to do his duty. She disguises herself as a man and volunteers for the same regiment or ship. Often she is her lover's cabin boy and he is her captain, admiring her brave obedience. When he is wounded, she nurses him. Overcome with gratitude, he remarks upon her similarity to the sweetheart he left behind, at which point, overcome with passion, she declares herself.

The value of the Female Warrior to a warring state, as Britain was throughout the eighteenth century, and its demand for continual supplies of men, is illustrated by The Female Volunteer, or an Attempt to make our Men Stand, an Account of the late action at Falkirk. Printed as a broadside in 1746 and priced, expensively, at sixpence, this theatrical epilogue was "intended to be spoken by Mrs Woffington, in the Habit of a Volunteer." The broadside's illustration adds a tri-corn hat and sword to Margaret 'Peg' Woffington's (1714-60) breeches, for which she was already famous in roles at Drury Lane, while her smock hangs in the shadowy background. Her ribald lament asks how men can be virile, if they do not fight for their country. 
Plague of all Cowards, say I, why bless my Eyes No, no, it can't be true - The Gazette lies.

Our men retreat before a Scrub Banditti !

Who scarce could fright the Buff coats of the City.

Well, if tis so, and that our men can't Stand,

Tis time we women take the Thing in Hand

Had we an army of such valorous wenches

What man, d'ye think, would dare attack our Trenches (Dugaw 53)

Such was the swashbuckling background to the disguise biographies, which emerged in mid eighteenth century for middle class readers and inflected familiar tropes for new circumstances. Female warrior biographies flourished throughout the eighteenth and nineteenth centuries up to the publication, in 1940 by an unknown publisher, of Dorothy Lawrence's autobiographical, The Only English Woman Soldier, Late Royal Engineers, 51 ${ }^{\text {st }}$ Division, 79th Tunnelling Company B.E.F (1919).

The tradition seems to begin in 1740 with Richard Montagu's publication of The Life and Adventures of Christian Davies, Commonly Called Mother Ross, who in Several Campaigns under King William and the Late Duke of Marlborough, in the Quality of a Foot Soldier and a Dragoon, Gave Many Signal Proofs of Unparalleled Courage and Personal Bravery, Taken from her Own Mouth when a Pensioner at Chelsea Hospital and Known to be true by many who were engaged in those great scenes of Action. Davies' authenticity, acknowledged by her receipt of a Chelsea Pension, offered a precedent for Hannah Snell, who also aimed for an army pension.

On $27^{\text {th }}$ May 1750, demobbed from the navy at Spithead in Hampshire, Snell arrived at her sister's house in Wapping, East London. Two and half years' pay consisted of $£ 15$ and two men's suits, which she sold for 16 shillings. Probably she wore her regimentals to the public house in Wapping, where on Sunday $9^{\text {th }}$ June, 1750, in the presence of witnesses, including her sister, her brother-in-law and former ship-mates, she declared herself a woman. This is already a performance, as was her life as a sailor, which was duly commemorated by a ballad, published in the London press.

Hannah in Briggs behaved so well

That none of her softer sex could tell,

Nor was her policy confounded

When near the nark of nature wounded

Oh how her bedmate bit his lips

And marked the spreading of her hips,

And cursed the blindness of his youth

When she confessed the naked truth. (The Female Soldier) 
The second verse refers to an offer of marriage from a shipmate, but Snell had a plan to support herself. A week later, on $16^{\text {th }}$ June, wearing regimentals, she stopped the Duke of Cumberland's carriage in Hyde Park. An infamous anti Jacobite, he must have been engaged by her claim that she had enlisted and marched after Bonnie Prince Charlie's retreat. The Duke of Cumberland accepted her certificate of wounding, delivered by Colonel Napier, and made her an out-pensioner at the Royal Chelsea Hospital on $£ 30$ a year. A week later, $23^{\text {rd }}$ June, The Whitehall Evening Post broke Snell's story, presenting her as a living ballad heroine: "Her Sweetheart being impressed... she put on man's clothes and entered into the same regiment."

However, it was Robert Walker, innovator in serialising books and producer of pirated and original editions aimed at the bourgeois novel reading class, who picked up the real scoop. On $27^{\text {th }}$ June 1750, Snell, who could read but not write, put him in sole charge of her story, through an affidavit, which she signed with a cross and presented to the Lord Mayor John Blachford. The affidavit summarised her male dress and described her injuries, which Walker, perhaps under dictation, wrote up as: The Female Soldier; or, the Surprising Life and Adventures of Hannah Snell ... Who Took Upon Herself the Name of James Gray; and, being Deserted by Her Husband, put on Mens Apparel, and ... enlisted in Col. Guise's Regiment of Foot, ... Also a full and true account of her enlisting afterwards into Fraser's Regiment of Marines. The frontispiece engraving carried a Pic by $G$ Scot. A Treatise for Fair Sex in order to prevent the publick from being imposed upon by fictitious accounts...printed and sold at the Corner of Eliot's Court in the Little Old Bailey - 1750.

Omnisciently narrating (except for two sections which Snell apparently tells directly in the first person), Walker begins the story by presenting Snell as the eighth of nine children. Her father, a Worcester dyer and hosier, married twice. The implication is that her courage was inherited from her grandfather, Sam Snell, a Captain Lieutenant who died at the battle of Malplaquet in 1709. By the time she was twenty, both parents were dead too. She moved to her sister's and brother-in-law's in Wapping, East London and married a Dutch sailor, Summs, who, unlike the ballad lover, was a whorer and thief. $\mathrm{He}$ abandoned Snell in her seventh month of pregnancy. When her daughter died at seven months old, Snell buried her in St George's churchyard, Middlesex. Taking her brother-in-law's name and clothes, she went to look for Summs and, at Coventry, enlisted in the infantry. On a night's leave or desertion, she accepted a drink and money from a friendly lieutenant and, although only the merchant navy could be legally press-ganged, she found herself in the marines under Colonel Fraser. She set sail on The Swallow sloop with Admiral Boscawen's fleet, to fight the French in India.

Walker's readership existed within a nation re-identifying itself as a nautical power. He emphasises the sacrifice of safety and comfort for any sailor 
in meeting bad weather at the Cape of Good Hope then enduring short rations of food and salt for 17 weeks and only a pint of water a day. Perhaps this worked well for Snell, who had to pass her urine through a leather horn. Her gender is continually close to being discovered by her shipmates, who call her Molly since she has no beard. Then her female solidarity - a warning to a woman whom a superior planned to deflower - leads to her corporal punishment. The trope of maritime sadism combines subjecting the transgressing female body to castigation designed for men with the trope of the innocent/fair unjustly punished. She is clapped in iron for five days at a gangway, given twelve lashes (intriguingly, no one noticed her breasts) and tied to the foretop masthead for four hours. Her valiant shipmates redeem manhood's honour by dropping a block on her oppressor's head.

In August 1748, she arrives at Cudalow to besiege Ponducherry. Waist deep in mud, she is wounded in both thighs. (Walker 171) This section is written, presumably for delicacy, as Snell's account of hospital in Cudalow, where she removes shot from her groin. Her only helper is an Indian woman from whom she requests a salve. She is released on $2^{\text {nd }}$ August 1749 into the warship Tartar and, on $13^{\text {th }}$ October, transferred to the leaky Eltham to sail for Portsmouth. Reaching Spithead on 25th May 1750 and discharged by Admiral Hawke, she sets off for London, escaping a landlady, whose hopes of marriage she has raised as part of her masquerade.

The modern historian, Matthew Stephens, draws attention to Walker's mismatched dates. Parish records at St George's, Middlesex, record a Susannah Sums, who may have been Snell's child, born in 1746. Snell may have spent 4 months or two years in the army. There is no record of Sam Snell. A sailor called James Gray from the ship Eltham was in Cuddelore hospital, under the care of surgeon William Belchier in September 1748 for 6 weeks, but that was after the attack on Devicotta. A James Gray (not her brother-in-law who died of consumption in 1764 in a workhouse) was buried at Royal Chelsea hospital, where Snell was buried, five days before her recorded death on $8^{\text {th }}$ Feb 1792, in Bedlam.

These mismatches emphasise that Walker was crafting a narrative rooted in facts that would chime with his public's expectations and curiosity. Ponducherry was more famous than Devicotta and a heroine with scurvy is less appealing than a heroine wounded in the groin. Her pension depended on her being wounded and a battle scar raises a soldier's social capital - provoking curiosity and a narrative, which may be embellished, of how the wound was come by. Although hard work and poor food may make periods irregular, (Freidan 166-7) Snell could have blamed menstruation on her wound. Once her secret was out, a wound in her groin could hardly fail to evoke the "wound" of the vagina which, from Latin, translates as "sheath", a place to store and protect 
a weapon, not to operate it from. If Snell did not know that, she knew how to surprise expectations.

The New Wells Spa theatre in Clerkenwell was a forerunner of Music Hall, offering songs, dances, mimes and acrobatics, for the price of a pint of wine. The entrance fee circumvented licensing laws, which restricted speaking on stage in London to Drury Lane and Covent Garden, ${ }^{2}$ for fear of inciting dissent or riot amongst gatherings of unprivileged people in an age notorious for uninhibited spectators. For her benefit night, for which she would have received all the profit, Mrs Yeates, wife of the manager, starred in The Sacrifice Of Iphigenia. The underlying myth of Mrs. Yeates's act was fashionable, probably because it represented a father who traded a daughter for a wind to take him where he needed to go (Troy) and, as such, allegorized fathers who disposed of daughters in convenient marriages. The lead role gave Mrs Yeates reason to wear as little as Elizabeth Chudleigh, later the bigamous Duchess of Kingston, who had appeared as Iphigenia in Ranelagh Gardens three years before. More than half naked, Mrs Yeates could hope to match, or top, Snell's preceding cross-dressed marching. Snell had to swear not to market prints of her portrait at the Wells. This suggests that she was a hard act to follow. Robert Walker describes how:

she and her attendants fill up the stage in a very agreeable manner... the tabor and drums give life to her march and she traverses the stage 2 or 3 times over step by step in the same manner as soldiers march on the Parade Ground in $\mathrm{St}$ James' Park... executes what she undertakes to admiration. (Walker 44)

The manual exercise could be learned from illustrated primers ${ }^{3}$ for the militias, which were also a source of eye-catching clothing. As Captain Teazable announces of his commission in Richard Cross's contemporary farce, The Henpecked Captain, "I love to see the Mob admire my cloathes as I march along." (I.1)

For the lower ranks, uniform might be brighter and better made than any other garments they possessed, therefore desirable as objects of relative luxury, as well as being badges of trained courage. Snell and her attendants were in a position to fuse sexual desire with desire for such clothing (Lock) and increase fascinated suspense by marching with arms that mere women might discharge, by accident or stupidity, in a crowded space. Dexterity and controlled discharge,

${ }^{2}$ At Drury Lane and Covent Garden theatres, where tickets were more expensive (boxes cost $2 \mathrm{~s} 6 \mathrm{~d}$, Stalls $1 \mathrm{~s} 6 \mathrm{~d}$, gallery 1s) and the audience perhaps more privileged, scripts were vetted by the Examiner of Plays.

${ }^{3}$ Cole's The Soldier's Pocket-Companion gave instruction with illustrations about how to "Poise your Firelock ... Join your Left Hand to your Firelock ... Cock your Firelock" and "Fire." 
would have underlined Snell's unique selling point as a professional soldier on the theatrical stage.

Snell founded the female manual exercise as a stage performance. However, working outside the West end playhouses may have put her into an uncertain category of "actress," and she is omitted from the account of cross-dressing actresses in Gill Perry's recent Spectacular Flirtations: Viewing the Actress in British Art and Theatre, 17681820. Walker was adamant that "she ... perform[ed] her Part as an able and experienced Actor. In this Branch of her Office she appears regularly dress'd in her Regimentals, from Top to Toe, with all the Accoutrements, requisite for the due Performance of her Military Exercises." (Walker 175) In a century of masquerade, in clothes which she had been used to wearing for a living without drawing attention - more like an extra than an actor, she had to maximise her visual appeal on stage. The height of the stage was a factor. Spectators standing in the stalls would have had an eyelevel view of breeched legs and the famous groin, whether or not, as Menie Muriel Dowie suggested in her introduction to Women Adventurers, "the ball in the groin was an impertinent addition for a circle of admirers at the Wells." Those at the front could have seen the relatively short skirts of her jacket, unbuttoned past the hips, opening as she strode. Probably like Farquhar's Sylvia, Snell took "a bold step, a rakish toss, a smart cock and an impudent air to be... the composition of a captain." (The Recruiting Officer IV.1)

In the course of about 60 performances between $29^{\text {th }}$ June and $6^{\text {th }}$ Sept $1750,{ }^{5}$ Snell extended her act by singing. If, as Walker would have it, she had been punished at sea for refusing to sing, (Walker 171) her "new song" performed "at the request of some ladies" and delivered in the costumes of tar and cabin boy, privileged the New Wells audiences. The ballads Britannia's gold-mine; or, the herring-fishery forever. A new ballad, to the tune of, There was a jovial beggar and The Jovial Tar were for sale at the bar. (General Advertiser) No doubt the East end audience were encouraged to sing along as a way of containing and directing any participatory energy and emotion.

The opening sentence of The Female Soldier commented on 'this dastardly Age of the World, when Effeminacy and Debauchery have taken [the] Place of the Love of Glory.' However, rather than interrogating male valour - no doubt there were both soldiers and sailors in the audience - Snell's ballads appealed to national pride. She may have been a woman but she represented all British sailors who "ventured on the main facing every danger, love and glory to obtain."

${ }^{4}$ Dowie included The Female Soldier in an edition of four stories, including Christian Davies in Women Adventurers.

${ }^{5}$ Announcements were carried in The General Advertiser, starting $29^{\text {th }}$ June 1750. Snell performed every night the theatre was open from $29^{\text {th }}$ June 1750 until $17^{\text {th }}$ August, when she had a break until $31^{\text {st }}$ August, before re-appearing on $17^{\text {th }}$ and $19^{\text {th }}$ September. 
In the midst of Blood and Slaughter

Bravely fighting for my King,

Facing Death from Every Quarter,

Fame and Conquest Home to Bring. (A NEW SONG)

Snell never had her own benefit night at the New Wells Spa. She was new to the business of theatre and probably could not afford to gamble expenses she must pay against profit she might earn. Nevertheless she went on tour to the provinces, performing in January 1751, in Marchant's Hall, Bristol and on $25^{\text {th }}$ February, in the New Theatre, at Bath. If these stage performances were her last, she retained her reputation. When she was "sent to the Bridewell for a misdemenour, the London Press referred to her as "Hannah Snell, the soldier." Her marriage to "a rich man, Sam Eyles," was announced in the press in 1759. 1789 records her son, George Spence Eyles, an attorney, collecting subscriptions for a cheap copy of her engraved portrait by Richard Phelps.

Snell's act was silently adopted by professional actresses later in the century and The Female Soldier was reprinted in Britain and America - notably in Isaiah Thomas's New England Almanac (1774), where she is shown wearing a dress short enough to reveal her ankles. A Northampton edition built on this daring femininity, prefacing the original title with The Widow in Masquerade (1809).

The Atlantic crossing of Snell's story and its popularity in North America almost certainly spurred impressarios connected with American fighting women to present their own versions of their experiences and to couple them to dramatic performance in America's newly reopened theatres. Hermann Mann's The Female Review or Memoirs of an American Young Lady (1797), also emphasises the femininity, in its respectable, honourable and maternal aspects, of Deborah Sampson. Sampson, born in Massachusetts was a working class woman, who disguised herself in her dead brothers' clothes and as Robert Shurtliffe, served three years in the American army. Allegedly, "published at the request of the audience" The Female Review was designed to support the first public speaking tour by a woman. It accompanied an Address, which Deborah Sampson performed on March 22nd 1802, at the Federal Street Theatre, Boston for the contemporary stage spectacle, The Soldiers' Festival. She performed it four successive nights of plays at Boston before touring it through New England and Eastern New York.

Public speaking was prized in the new United States as a way of constructing and advertising a cultured American profile, ${ }^{6}$ which would honour to the land of the free and spread information about its history and geography.

${ }^{6}$ See part $111,11^{\text {th }}$ edition of Webster's An American Selection of Lessons in Reading and Speaking. 
Sampson drew, according to the few notes which she kept on tour, 'a very respectable ordience[sic],' (Young 210-11) of both sexes and she praised, in particular, the women's attention. The style of her performances attracted as much commentary as its content. A correspondent identified as 'Gill Blass,' from The Hampshire Gazette, observes in his "panegyric", "the numerous respectful and admiring audience ... the elegant dection [sic], the manly elocution... she is beautiful in an eminent degree." (Masquerade 209-10) Hermann Mann presented her as "rather masculine and serene than effeminate and sillily jocose" (134). At the same time he insisted she was "Wife, Mother and Friend... affable in her disposition, courteous in her manners and universally benevolent" and suggested she paid him to write the speech: "Honourably [to] enhance the pecuniary interests of her family she accordingly procured... [and] remarkably soon committed verbatim to memory except an addition since of about 3 pages." After the oration, as with Hannah Snell, came her manual exercise, delivered with the "facility and dispatch," which her survival and cover in the army would have depended on.

Sampson was introduced by an attendant, presumably a professional performer who could speak verse, when, as Mann suggests, Sampson was too "unlettered" and "uncouth" (Mann 134) to speak anything but prose. However the verse stresses her commitment to the values of the Revolution.

Her boldest claim is simple genuine Truth

Her humblest plea is for her sex and youth...

Even Britain's Fair, though proud, this Truth must own,

When Liberty's at stake a female storms the throne.

Sampson's modern historian, Judith Hiltner, notes that Mann's "agenda ...shaped his appropriation of her experience," (Hiltner 191) which may explain Sampson's request that the biography should not be published until after her death. However, Alfred F. Young suggests that Sampson worked closely with Mann in order not to appear a "modern baggage worse then a Libertine or debauchee" and be denied the army pension she had earned (189). Unlike Walker's ventriloquizing of Snell and Snell's sassy performance on stage, Mann made Sampson deferential. The speech he wrote her was an apologetic confession, aiming to "correct the breach of indecorum" caused by perception of an injustice. As a "lost child" or "bewildered star travelling out of its accustomed orbit" she declares, "My mind became agitated... why a nation, separated from us by an ocean... should endeavour to force on us plans for subjugation." Finishing her address as Mrs Gannet, a married mother, she would "readily acquiesce in the acknowledgement that the field and the cabinet are the proper spheres for our Masters and Lords...leaving women with kitchens and 
parlours... Our best hope is to be mistress and lady and to rear our offspring as worthy to fill the most illustrious stations of their predecessors."

Like Walker, Mann raises his heroine's relationship with key moments of the war. He invents her direct experience of the battles of White Plains, Charlestown, York Town, Breed's Hill (Mann 54, 67-8) and General Schuyler. Whilst it could easily be true that Sampson lost toenails to frost bite, and, like Snell, would have reason to extract a ball from her thigh herself, her presence as "one of the unhappy crowd" at the notorious Philadelphia Hospital is an invention too. However, The New York Gazette (1784), ${ }^{7}$ which announced her masquerade and the "violent illness that disclosed the disguise," invented too. To the detail of the 'small shot remaining in her to this day', this unsigned article attributed "the cause of her personating a man...[to] the rigour of her parents...to induce a marriage with a young man she had conceived a great antipathy for." (Young 4) This invokes the old trope of the lover catalysing the masquerade. The difference is that the lover is present and unwelcome as opposed to absent and missed.

The Female Review makes the catalyst a "dream of a serpent that became an ox which she cut to pieces and then saw was only jelly." The allegory of Sampson as St George, and Britain as the shape-shifting monster, would have resonated with the United States' historical identification with religious freedom, evident in the influence of Quakers and Baptists, who credited women with the same spiritual power as men. Sampson had been a Baptist and Mann had represented himself as 'a clergyman,' which may explain the apocalyptic ring to the description of the cannonade at Charlestown: "Many have doubtless seen the meteor streaming through or breaking in the horizon - the terrific glare of the comet, in its approach towards or in its declension from us, in its excentric orbit, the howling of a tempest."

A high moral tone underlines the purpose of Sampson's disguise. She corrects an officer who calls a shabbily dressed woman visiting the camp a "slut": "Elegance in dress Sir becomes the fair as well as your sex but how should that soldier feel who values himself highly for his courage, his great exploits etc, (perhaps where there is no real danger) should they forsake him in the field of battle?" This is a prim version of Snell's warning to the woman in danger of seduction, and instructs men on what women expect of gallantry. When "a young lady conceives an attachment for one Blooming Soldier" (Mann 186) and falls in love with Sampson, to the point of having hysterics when Sampson leaves, "Our galantress" (173) returns to calm her. Her care is for others, despite the risk to her own health through small pox, when avoiding "the exposure of my person" she tells "a plump lie to the surgeon ... that I had long

\footnotetext{
${ }^{7}$ The article was later reprinted in Boston.
} 
since experienced that disease..." Opting to be left behind by her colleagues to tend a wounded man, she then fights wild cats away from his corpse. Chapter 11 offers more fighting and caring in "A hunting tour in which she kills her Indian Companion and ...liberates an English girl, condemned to be burned by natives". Her femininity alerts her to Widow Hunt. "Our heroine, more acquainted with the cunning of her sex, advised them not to adhere to her smoothness of speech."

The Life of Pauline Cushman is built on female cunning, although inadequate to prevent the protagonist's near execution, as the full title announces: The Life of Pauline Cushman, the celebrated Union spy and scout comprising her early history, her entry into the secret service of the army of Cumberland, and exciting adventures with the rebel chieftains and others while within the enemy's lines: together with her capture and sentence to death by General Bragg and final rescue by the Union Army under General Rosecrans. Through a reference to other 'young women found in male attire' (Sarmiento 108), The Life of Pauline Cushman acknowledges accounts of other women, who fought as soldiers in the Civil War. ${ }^{8}$ However, this biography is not about playing one part as a male soldier. It is about playing many parts - on stage, where the protagonist's acting career begins and in the "real" life of a country at war, as she uses her talent to "act" for the Union.

The roles of spy and scout demand versatility and depend on secrecy, which gives enormous scope for narrative invention. F.L Sarmiento, presenting himself as "Member of the Philadelphia Bar", and the account as "carefully prepared from her notes and memoranda" (Sarmiento 1), exploited this scope to craft a cross-dressing action-adventure romance. The protagonist's manifestations cross class as well as gender. She can be "a rough country boy" (Sarmiento 69) or a "young Southern gentleman of means."(70) Her many romantic conquests include a Native American, to whom she is Laughing Breeze, and a female ex-soldier who offers to be her slave. As "Captain Denver", she acts as agent provocateur and lures and traps Mrs Ford, a Southern agent provocateur. So that men are not left out of cross-dressing fun, "a young gentleman was forthwith dressed as a woman and introduced to General John Morgan as Miss Sue Monday, a dashing and fearless Young lady, ready to join the Confederate service."

The popularity of cross-dressing in the mid to late nineteenth century, at least to voyeurs, is clear from the prevalence of cross-dressing stage acts supported, increasingly, by cross-dressing photographs. Acting sisters Charlotte (1816-76) and Susan Cushman 1822-59) inspired a ceramic model of them performing a lovers' embrace as Romeo and Juliet. The ceramic was modelled on an engraving of their performance at the Haymarket, London, where billed as

\footnotetext{
${ }^{8}$ See An uncommon soldier.
} 
American Indians, they had played for eighty nights in 1845, before touring the performance through England. Charlotte played Romeo to high critical acclaim.

Pauline Cushman did not claim a family connection with the Cushman sisters, but surely sharing their name boosted ticket sales for appearances as "Miss Major Cushman" (also reproduced as a carte de visite) - at the Assembly Buildings in Philadelphia from $10^{\text {th }}$ to 23 rd October in 1864 . The playbill of Tuesday $11^{\text {th }}$ October warns of "hundreds unable to gain admission." The playbill of Thursday $13^{\text {th }}$ advises: "to avoid the crowds in the evening it is respectfully suggested that seats be procured during the day." What promised, and probably delivered such popularity given its fortnight's run, was a "Grand Combination" of her "Startling Adventures, a Stereopticon of European Scenery, her Trial and Sentence to Death and Rescue and One Thousand views of American Scenes." Pauline Cushman seems to have performed solo impersonations, which, like the prose narrative, "endeavoured to gather about our recital of these most curious and interesting adventures, all the incongruous characters that one sometimes meets with in the world at large." (Sarmiento 372)

Her appearance in "Parlor Costume!!!" added to the playbill of $20^{\text {th }}$ October, suggests the audience had become curious about her female identity and, in response, she played up an extreme femininity. The biography (Sarmiento 37) supports this with an undated "extract from a New York paper":

This famous Federal scout and spy, major Pauline Cushman, is now in New York, attracting much attention. Few if any of our American women have rendered the Federal cause such in estimable service as this bold and beautiful lady. These services have been appreciated by government and by generals in the field, and their letters, testimonials and personal acknowledgements prove their love and esteem for this truly loyal lady. In appearance Miss Cushman is lavishly endowed with the wealth of nature. Her form is perfect, so perfect that the sculptor's imagination would fail to add a single point or banish a single blemish. Her arm is equally beautiful, resembling in mould the marble effects seen in the great art galleries of Europe. The outlines of her face are of exceeding beauty and the perfect features set off to the best advantage by a pair of large flashing black eyes, which look out with a keen brilliant expression. Miss Cushman's hair is as black as night but those who have seen her at the front would hardly recognise her. Then she was obliged to assume numerous disguises - at times figuring as a private soldier, again acting the clerk, now on a scout, and often as a temporary officer upon some general's staff. With all of this stern experience and hardship of actual campaigning - entered into from a pure love of liberty - Miss Cushman is still the full possessor of all those accomplishments that characterize her sex. With the purest motives and ardent devotion to country, she has seen war in all its phases without being dazzled by its glitter or contaminated by its corrupting influences.

In contrast to Snell and Sampson, Cushman's claim is that war has not scarred her or her female and feminine parts. However like them, she 
has sacrificed "health, means and every comfort" (374) and now warrants financial support, which the narrative requests from the audience: "May we not appoint you, the beautiful Genius of Good, loved public and ask you to award, as you alone can award, the thanks and gratitude as well as the more tangible help, which has been so justly earned by Pauline, the Scout and Spy of the Cumberland?" (374)

The grim reminder that "Generals Bragg and Forrest are each alive at this writing, and each still holds command in the rebel service" (Sarmiento 373) offers verisimilitude to a story, which depends for verification on the absent, the dead, the enemy or those who keep silent to protect themselves and others. This suggests that Major Pauline Cushman was a timely fantasy, whose real service to the Union was a theatricalisation of women's co-option into a war that was yet to be won. Whilst confronting traditional expectations of her gender by earning her own living, as well as, probably, money for her managers and agents, she was endorsing the Union's attempt to build a new nation. In a similar way, Hannah Snell in Britain and Deborah Sampson in early New Republic America, whilst surpassing gender expectations to earn a wage and claim a pension, were also investing in national patriotic agenda through their narratives and stage performances.

\section{Works Cited}

Allen Billings, Eliza. The Female Volunteer, or an Attempt to make our Men Stand, an Account of the late action at Falkirk. Print.

An uncommon soldier: the Civil War letters of Sarah Rosetta Wakeman, alias Private Lyons Wakeman, 153rd Regiment, New York State Volunteers. Oxford: Oxford University Press. 1995. Print.

A NEW SONG. Sung by HANNAH Snell, alias JAMES Gray, at the New-Wells Goodman's Fields. 1750. Print.

Cole, Benjamin. The Soldier's Pocket-Companion, Or The Manual Exercise Of Our British Foot 1746. Naval \& Military Press. 2006. Print.

Cross, Richard. The Henpeck'd Captain; or The Humours of the Militia (1748). Larpent collection MS 71, Huntington Library, San Marino, California. Print.

Davies, Christian. The Life and Adventures of Christian Davies, Commonly Called Mother Ross, who in Several Campaigns under King William and the Late Duke of Marlborough, in the Quality of a Foot Soldier and a Dragoon, Gave Many Signal Proofs of Unparalleled Courage and Personal Bravery, Taken from her Own Mouth when a Pensioner at Chelsea Hospital and Known to be true by many who were engaged in those great scenes of Action. London: R. Montagu. 1740. Print.

Dekker, Thomas and Thomas Middleton. The Roaring Girl. 1609. Print.

Dowie, Menie Muriel, ed. Women Adventurers. London, TF Unwin. 1893. Print. 
Dugaw, Dianne. Warrior Women and Popular Balladry 1650 - 1850. Cambridge: Cambridge University Press. 1989. Print.

Farquhar, George. The Recruiting Officer. A comedy. As it is acted at the Theatre Royal in

Drury-Lane, by Her Majesty's servants. 1706. Print.

Freidan, Betty. The Second Stage. New York: Harvard University Press. 1981. Print.

Fulford, Tim. "Fallen Ladies and Cruel Mothers: Ballad Singers and Ballad Heroines in the Eighteenth Century". Eighteenth Century, Theory and Interpretation 47 (2006). 309-29. Print.

Hiltner, Judith. "She Bled in Secret: Sampson, Hermann Mann and The Female Review". Early American Literature. 34 (2) (1999).190-220. Print.

Jelinek, Estelle C. "Disguise Autobiographies, Women Masquerading as Men". Women's Studies International Forum. 10 (1987). 53-62. Print.

Lock, Georgina. Short, White, Pleated. DVD. Handstand Films. 2002.

Mann, Herman. The Female Review or Memoirs of an American Young Lady. Dedham, Mass.: N. and B. Heaton. 1797. Print.

Pepys, Samuel. The Pepys Ballads. Vol. IV. Hyder Edward Rollins ed. Cambridge, Mass.: Harvard University Press. 1929. Print.

Perry, Gill. Spectacular Flirtations: Viewing the Actress in British Art and Theatre, 1768- 1820. New Haven, CT: Yale University Press. 2007. Print.

Sarmiento, F.L. The Life of Pauline Cushman. Philadelphia: John E Potter, Sanson Street. 1865. Print.

Stephens, Matthew. The Secret Life of a Female Marine, 1723 -1792. London: Ship Street Press. 1997. Print.

The Female Officer, or the wonderful startling and thrilling Adventures of Madeline Moore, Who to be Near her Lover Procured a Male Disguise, and joined the late Expeditionary force to Cuba, was elected Lieutenant and fought in the Battle of Cardenas, Under the Renowned General Lopez, An Accurate Description of the Battle, and her own Perilous Adventures and Hair Breadth escapes including those of her Lover and a Great Deal More of Like Nature, Are Described with a Graphic Power That Will Fairly Make Onee's Blood Tingle With Excitement. The reader may rely upon this narrative, as being strictly authe ntic. New York. 1851. Print.

The Female Soldier. London Evening Post. July 5 - July 7. 1750. Print.

The Friendless Orphan, An Affecting Narrative of the trials and Afflictions Of Sophia Johnson, the early Victim of a Cruel Stepmother, whose afflictions and adventures probably exceed those of any American female living. Pittsburgh, PA.1842. Print.

The General Advertiser, $29^{\text {th }}$ June 1750 . Print.

The life, travels and extraordinary adventures of Elizabeth M'Dougald, who attired as a man, travelled over the principal part of the United States and of Canada, between the years 1826 and 1834 for the avowed purpose of revenge and assassination, and who, during her travels, spent two years in the army of the United States, without having her sex detected. Providence, SS Southworth. 1834. Print.

The New York Gazette, $10^{\text {th }}$ January 1784. Print. 
The Widow In Masquerade or the Female Warrior; Containing a Concise Narrative of the Life and Adventures of the Hannah Snell, Who Served With Credit for Several Years in the British Army and Navy. Northampton, Mass. 1809. Print.

The Woman in Battle: A Narrative of The Exploits, Adventures, and Travels of Madame Loreta, Janeta Vasquez, otherwise known as Lieutenant Harry T Buford, Confederate States Army, in which is Given Full Descriptions of the Numerous Battles in which she Participated as a Confederate officer; Of Her Perilous Performances as a Spy, as a Bearer of despatches, as a secret service agent, and as a Blockade Runner; of her adventures behind the Scenes at Washington, Including the Bond Swindle; of her Career as a Bounty and Substitute Broker in New York; of her Travels in Europe and South America, her mining Adventures on the Pacific Slope; her residence among the Mormons; her Love Affairs, Courtships, Marriages etc. etc. Ed. Worthington CJ. T Belknap, Hartford, CT. 1876. Print.

Thomas, Isaiah, ed. "The Life and Adventures of a Female Soldier". New England Almanac. Boston, Mass. 1774. Print.

Walker, Robert. The Female soldier, or, The surprising life and adventures of Hannah Snell. 1750. Print.

Webster, Noah. An American Selection of Lessons in Reading and Speaking Calculated to Improve the Minds and Refine the Tastes of Youth and also to instruct them in the Geography, History and politics of the United States to which are prefixed rules in Elocution and Directions for Expressing the principle Passions of the Mind. $11^{\text {th }}$ edition. Boston, Mass. 1797. Print.

Wheelwright, Julie. "Amazons and Military Maids, an Examination of Female Military Heroines in British Literature and the Changing Construction of Gender." Women's Studies International Forum, 1987 Vol 10 (5) 489- 502 Print.

Young, Alfred P. Masquerade, The Life and Times of Deborah Sampson, Continental Soldier. New York: Alfred A Knopf. 2004. Print. 